Marilia Barrichello

\title{
Devagar: como um movimento está desafiando o culto da velocidade
}

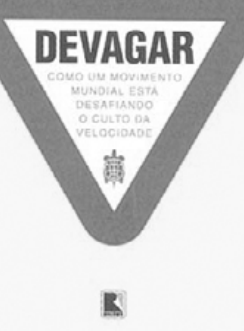

A capa em amarelo e vermelho, cores emprestadas do chamado mundo fast (rápido) chamam a atenção e contrastam com o título Devagar, bem destacado e o ícone da tartaruga. Mais do que um paradoxo, um indício da problemática da velocidade trabalhada no livro e reflexo de uma estratégia bem clara: chamar a atenção dos cidadãos acelerados e fazer um convite a reflexão. Por que estamos sempre correndo contra o relógio? A pressa, uma constante em nossas vidas, tem uma razão real? O que pode e o que não deve ser apressado? O que significa ser rápido e o que significa ser devagar? Como encontrar o tempo certo das coisas?

São essas as principais questões que Honore nos coloca ao longo dos seus capítulos temáticos que pouco a pouco conquistando, instigando e envolvendo o leitor, pois falar de velocidade é fazer pensar na vida, na relações, no tempo e no seu passar.

Como o pano de fundo do livro já parte de uma percepção cada vez mais coletiva e compartilhada de que o tempo se esvai numa toada cada vez mais curta e acelerada é impossível não sentir-se incluído no discurso de Honore como personagem coadjuvante do livro. Quem não se identifica com a constatação de que falta tempo para fazer o hobby da semana, jogar futebol com os amigos, participar mais da escola dos filhos? Asfixiados, parece que entramos numa dança frenética e que nossos pés saíram do controle. Estaríamos condicionados à velocidade e transportando-a sem julgamento ou necessidade para o trabalho, o lazer, a alimentação, a convivência?

É cada vez mais comum a crítica de que estamos fartos de agendas enlouquecidas, da falta de tempo para a família, para o lazer, para o prazer, para o ócio. O livro nos traz um alento quase filosófico ao mostrar que uma minoria de rebeldes está fazendo o impensável em busca de novos caminhos, contestando a velocidade e criando um estilo de vida mais equilibrado e qualitativo. Nos muitos e diversos atos de desaceleração dessas pessoas encontram-se as sementes de um movimento global em favor da lentidão.

(1) HONORÉ, Carl. Devagar. Rio de Janeiro: Record, 2005.

Marilia Barrichello, formada em Propaganda e Marketing pela ESPM, pós-graduada em Gestão da Comunicação Organizacional e Relações Públicas pela ECA-USP. Consultora de Branding da Alexandria Brasil.
Mas seria mesmo Devagar um movimento? Honore caracterizou-o como tal, mas evitou discussões teóricas sobre o que elevaria Devagar ao status de movimento, já que ao longo da leitura nos faltam elementos que justifiquem a coesão, coerência e a formalização.

É fato que o cerne do livro está muito mais centrado no contexto e na discussão do Devagar, enquanto filosofia e possibilidade do que nas bases necessárias para sua efetiva realização. Honore nos mostra que é possível desacelerar o ritmo e trilhar um novo caminho mais saudável, mais humano e mais prazeroso. Uma tentativa de fazermos as pazes com o tempo e minimizar a sensação de que estamos deixando 
algo pelo caminho. Tempo sem volta. Tempo não volta.

Sobre o ato de ser Devagar, o mesmo está centrado em um melhor aproveitamento do tempo livre, na adesão de um estilo de vida mais simples, ou seja, mais focado em valores essenciais e menos no consumismo e, por fim, na mudança de atitudes cotidianas e rotineiras. A adesão a tais mudanças e consequentemente a filosofia Devagar parece estar ligada a fatores complexos, principalmente, a relação com o tempo, relação com o sistema capitalista e, finalmente, com as tradições sociais e culturais. Culturas orientais têm a peculiaridade de ver o tempo de forma cíclica. Para elas, o tempo está sempre indo e vindo, renovando-se. Já para a cultura ocidental, o tempo é linear, finito e precioso. Tal fato não impactaria numa relação com o tempo mais mercantil e utilitária?

Apesar disso, Honore acredita que no Brasil existam fatores bastante propícios para o desenvolvimento do Movimento Devagar: forte contato humano pouco encontrado em países como Inglaterra e Estados Unidos e a valorização do prazer, seja na música, na dança, na socialização e até nos dias de carnaval. Tais fatores funcionariam como um freio para a velocidade e uma vacina contra o vírus da pressa.

Assim, a principal contribuição que a filosofia Devagar pode nos proporcionar, segundo o autor, é a conquista do equilíbrio, que possibilita uma melhor qualidade de vida, a partir de um questionamento sobre quais são as prioridades e as reais necessidades de cada um de nós. Também a capacidade individual de escolher quando ser rápido e quando ser devagar, encontrando o tempo giusto das coisas. Porém, esse conceito configura-se um paradoxo à medida que mudar de marcha acaba sendo um conceito mais plausível quando se está fora do tempo coletivo da esfera do trabalho.

Devagar não é ir contra tecnologias e ir no ritmo da tartaruga, mas sim buscar constantemente a busca do equilíbrio como algo relativo. Nesse ponto, o estímulo do livro remete a busca do significado real das coisas, dos pequenos momentos e das coisas simples que a vida oferece que vez ou outra passam batido.

No âmbito da reflexão e da inspiração a contribuição do livro é incontestável. Honore nos aciona a luz vermelha e nos faz parar, como a proposta da capa do livro e nos traz dados e exemplos concretos que fazem pensar sobre uma nova alternativa de vida. Porém, o "como" chegar lá é algo pouco explorado no livro. Existem alguns exemplos centrados, contudo, nos países desenvolvidos e algumas ressalvas ao número de habitantes que determinada cidade deve ter para ser mais propícia ao Devagar, a legislação e a própria relação cultural com o tempo.

O tom do livro é amigo, claro e otimista nos deixa esperando algum tipo de receita mágica para de uma vez por todas colocar vida nos eixos. E aí ficamos órfãos pela própria identidade recente e volátil do Devagar ainda em bases de construção. Ao final da leitura, entre muitas vontades de mudança, emergem duas perguntas fundamentais: Será o movimento Devagar sustentável em nossas bases macro-econômicas atuais? Será que estamos dispostos a abrir mão de certas regalias e benefícios em função de uma vida mais equilibrada e simples? Só o tempo vai dizer. 